Brief Report

\section{CONFLICTS OF INTEREST}

The authors have nothing to disclose.

\section{ORCID}

YoungHwan Choi, https://orcid.org/0000-0003-4177-7724

Donghwi Jang, https://orcid.org/0000-0002-3495-4772

Hyun Jeong Byun, https://orcid.org/0000-0002-4354-5655

Se Jin Oh, https://orcid.org/0000-0001-7525-4740

Cho Rok Kim, https://orcid.org/0000-0003-4168-4245

Ji-Hye Park, https://orcid.org/0000-0002-6699-5202

Jong Hee Lee, https://orcid.org/0000-0001-8536-1179

Dong-Youn Lee, https://orcid.org/0000-0003-0765-9812

\section{REFERENCES}

1. Hong J, Bernstein D. A review of drugs that induce or exacerbate psoriasis. J Psoriasis Psoriatic Arthritis 2012;18:2-11.

2. Kurtulus S, Sakuishi K, Zhang H, Joller N, Tan D, Smyth M, et al. Mechanisms of TIGIT-driven immune suppression in cancer. J Immunother Cancer 2014;2(Suppl 3):O13.

3. Dixon KO, Schorer M, Nevin J, Etminan Y, Amoozgar Z, Kondo T, et al. Functional Anti-TIGIT antibodies regulate development of autoimmunity and antitumor immunity. J Immunol 2018;200:3000-3007.

4. Voudouri D, Nikolaou V, Laschos K, Charpidou A, Soupos $\mathrm{N}$, Triantafyllopoulou I, et al. Anti-PD1/PDL1 induced psoriasis. Curr Probl Cancer 2017;41:407-412.

5. Wang FF, Wang Y, Wang L, Wang TS, Bai YP. TIGIT expression levels on CD4 + T cells are correlated with disease severity in patients with psoriasis. Clin Exp Dermatol 2018; 43:675-682.

\title{
Cutaneous Plasmacytosis Showing a Neuronal Involvement in a 35-Year-Old Female
}

\author{
Joong-Heon Suh, Ho-Young Kim, Jae Ho Lee, Soo-Kyung Lee, Un-Ha Lee, Myoung-Shin Kim \\ Department of Dermatology, Sanggye Paik Hospital, Inje University College of Medicine, Seoul, Korea
}

\begin{abstract}
Dear Editor:
Cutaneous plasmacytosis $(\mathrm{CP})$ is a rare skin disorder characterized by multiple reddish-brown patches and nodules that mainly occur on the trunk in adults ${ }^{1}$. Histologically, there is a dermal infiltrate of mature plasma cells. We re-
\end{abstract}

Received January 23, 2019, Revised July 29, 2019, Accepted for publication July 31, 2019

Corresponding author: Myoung-Shin Kim, Department of Dermatology, Sanggye Paik Hospital, Inje University College of Medicine, 1342 Dongilro, Nowon-gu, Seoul 01757, Korea. Tel: 82-2-950-1131, Fax: 82-2931-8720, E-mail: etihwevol@naver.com

ORCID: https://orcid.org/0000-0002-0660-8098

This is an Open Access article distributed under the terms of the Creative Commons Attribution Non-Commercial License (http://creativecommons. org/licenses/by-nc/4.0) which permits unrestricted non-commercial use, distribution, and reproduction in any medium, provided the original work is properly cited.

Copyright $($ c The Korean Dermatological Association and The Korean Society for Investigative Dermatology port a case of 35-year-old female who presented with multiple red to brownish macules and patches on the left side of the trunk with a neuronal distribution (Fig. 1). The lesion appeared 4 years ago without any symptoms of pain or itching. A histopathological examination revealed a dense dermal patch-like cellular infiltration surrounding the follicles and the nerves (Fig. 2). The infiltrate was composed of lymphocytes, histiocytes, and plasma cells. Immunohistochemical staining was positive for CD138, CD3, and CD20. Serum protein electrophoresis and immunoelectrophoresis revealed polyclonal hypergammaglobulinemia. Based on these findings, a diagnosis of CP was made. The patient underwent treatment with systemic corticosteroids and narrowband ultraviolet B for 3 months till date. However, the response to the treatment has been minimal.

In our review of the literature, skin manifestations of $\mathrm{CP}$ were considerably uniform among patients, with multiple reddish to brownish colored scaly patches, nodules, and 

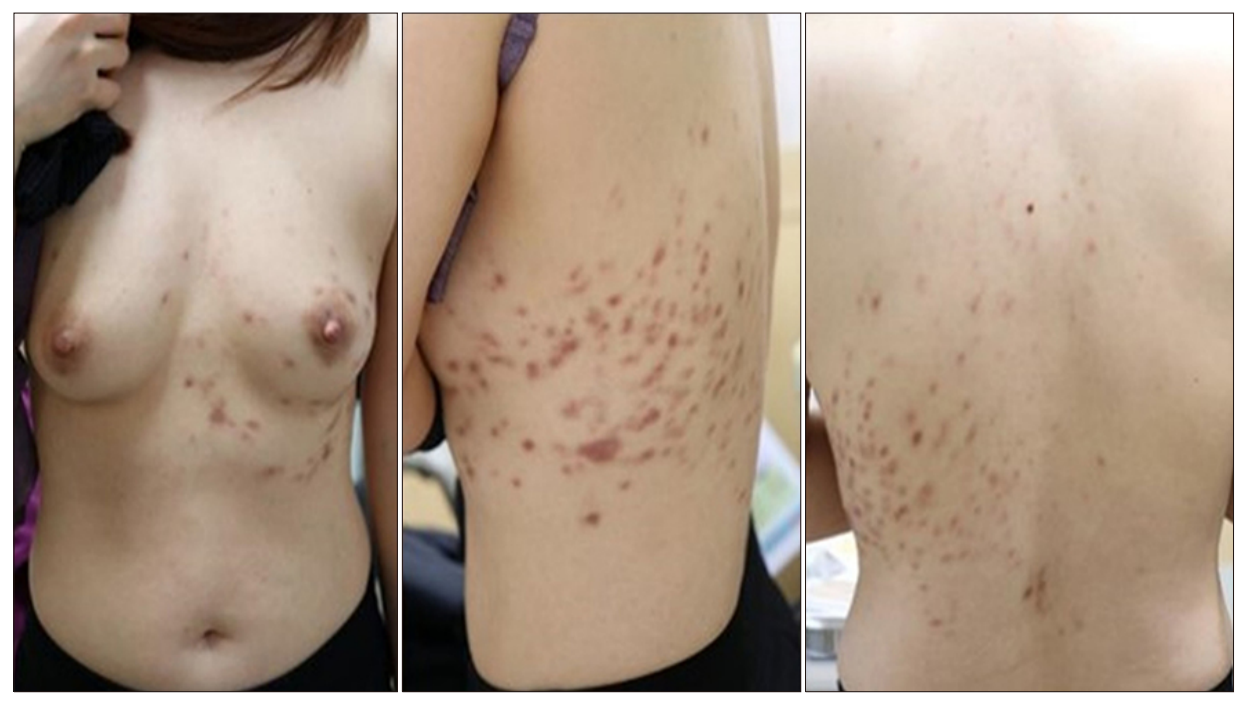

Fig. 1. Multiple red to brownish maculopatches in the left side of the trunk showing a neuronal dermatosis. We received the patient's consent form about publishing all photographic materials.
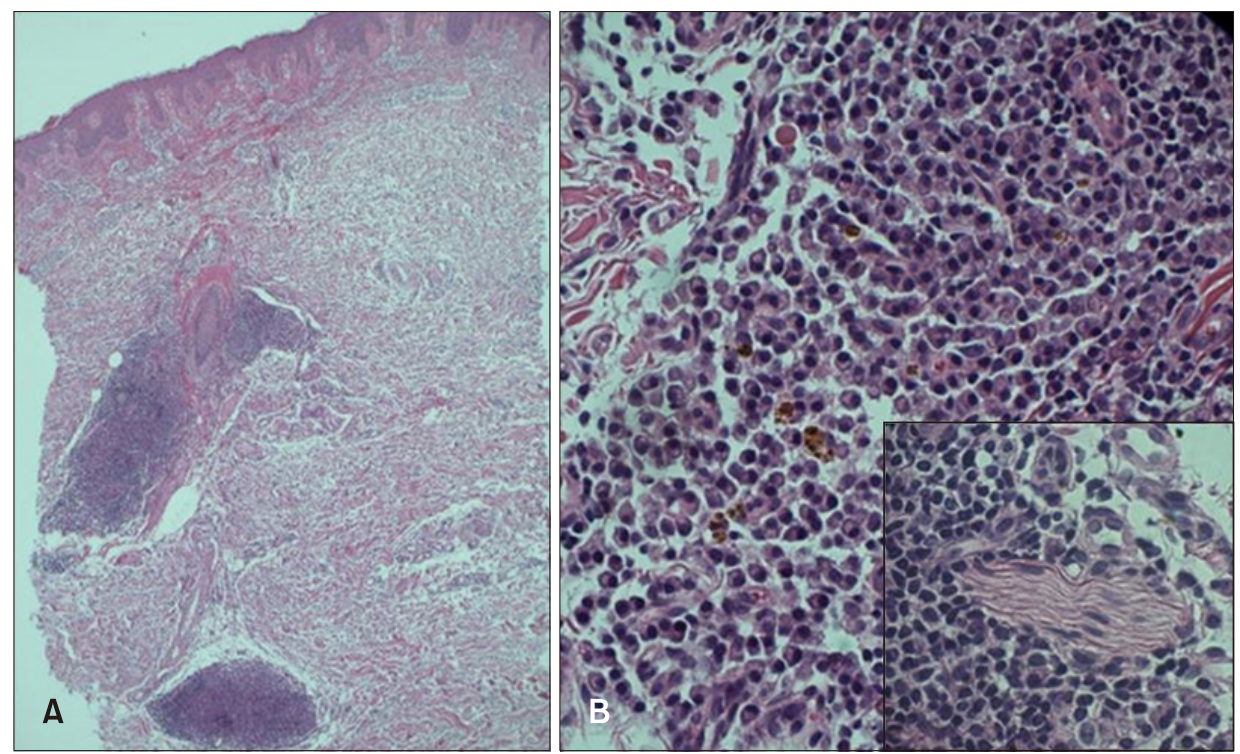

Fig. 2. (A) Lymphoid follicle-like nodular cell infiltrates in the middle and deep dermis intermingled with sparse interstitial cell infiltrates (H\&E stain, $\times 40)(B)$ Nodules are composed of plasma cells without atypia. Plasma cells are surrounding the neuron (H\&E stain, $\times 400$; inlet, $\times 400$ ). infiltrated plaques. Moreover, they were usually persistent, asymptomatic, or mildly pruritic and were mainly distributed on the chest or back in a symmetrical or "Christmas tree" like pattern, which may require precise differential diagnosis including pityriasis rosea and small patch parapsoriasis $^{1,2}$. Several other cases with facial or scalp involvement demonstrated a typical trunk involvement pattern as well ${ }^{2}$. Interestingly, in our patient, the distribution of the lesion showed an atypical pattern, affecting only the left side of the body and showing neuronal pattern dermatoses.

The histopathologic findings characteristically show dermal nodular and perivascular/periadnexal cell infiltrations with predominance of plasma cells admixed with variable numbers of lymphocytes and histiocytes ${ }^{3}$. Recently, Honda et al. $^{3}$ reported 6 cases of $\mathrm{CP}$ all showing the perineural and intraneural distribution of plasma cells. Similarly, in our patient's punch biopsy specimen, we observed perineural plasma cell infiltration. In this case, we hypothesize that the numerous plasma cells aggregated around the nerve fiber may have a correlation with the unilaterally neuronal pattern of the skin lesions. Furthermore, the typical symmetric pattern of $\mathrm{CP}$ on the chest or back may be a phenotypic expression reflecting its close relationship to the spinal nerve tract distribution.

Protein electrophoresis and immunoelectrophoresis generally show polyclonal increase in the gamma globulin fraction in major portion (84\%) of the CP patients ${ }^{2}$. However, the direct relationship between polyclonality and etiology of $\mathrm{CP}$ is unclear. If monoclonality is observed, it is necessary to exclude the possibility of marginal zone B cell lymphoma. Polymerase chain reaction for 
immunoglobulin heavy chain gene rearrangement and B-cell lymphoma 2 staining would be helpful to make the diagnosis clear ${ }^{4}$.

In summary, a diagnosis of CP should be considered when dermatologists encounter cases of asymptomatic neuronal pigment dermatosis. We speculate that further investigations on the association of the neural pathway with respect to the pathophysiology would be helpful to improve our understanding about CP.

\section{CONFLICTS OF INTEREST}

The authors have nothing to disclose.

\section{ORCID}

Joong-Heon Suh, https://orcid.org/0000-0002-1046-0487

Ho-Young Kim, https://orcid.org/0000-0002-1029-3287

Jae Ho Lee, https://orcid.org/0000-0002-3872-0527

Soo-Kyung Lee, https://orcid.org/0000-0002-7460-5657
Un-Ha Lee, https://orcid.org/0000-0003-1626-5583

Myoung-Shin Kim, https://orcid.org/0000-0002-0660-8098

\section{REFERENCES}

1. Uhara $H$, Saida $T$, Ikegawa $S$, Yamazaki $Y$, Mikoshiba $H$, Nijoh S, et al. Primary cutaneous plasmacytosis: report of three cases and review of the literature. Dermatology 1994; 189:251-255

2. Haque M, Hou JS, Hisamichi K, Tamada K, Cusack CA, Abdelmalek $\mathrm{M}$, et al. Cutaneous and systemic plasmacytosis vs. cutaneous plasmacytic castleman disease: review and speculations about pathogenesis. Clin Lymphoma Myeloma Leuk 2011;11:453-461.

3. Honda R, Cerroni L, Tanikawa A, Ebihara T, Amagai M, Ishiko A. Cutaneous plasmacytosis: report of 6 cases with or without systemic involvement. J Am Acad Dermatol 2013;68:978-985.

4. Han XD, Lee SSJ, Tan SH, Chong WS, Ng SK, Ooi MGM, et al. Cutaneous plasmacytosis: a clinicopathologic study of a series of cases and their treatment outcomes. Am J Dermatopathol 2018;40:36-42.

\title{
Expression of Human Herpes Virus 6, 7, Epstein-Barr Virus and Cytomegalovirus in Patients with Diverse Adverse Cutaneous Reactions to Drug
}

\author{
Young-Wook Ryoo, Joon-Bum Lee, Won-Oh Kim, Sung-Ae Kim \\ Department of Dermatology, Keimyung University School of Medicine, Daegu, Korea
}

Dear Editor:

Various drugs can cause diverse cutaneous adverse drug reactions $(\mathrm{CADR})^{1}$. Factors have been implicated in CADR, including the dosage, duration of use, physiological status and genetic background of the patient ${ }^{1}$. In addition, current or past viral infection has been reported to affect the occurrence of CADR ${ }^{2}$. In particular, many authors have suggested the activation of human herpes virus (HHV) 6 ,

Received March 18, 2019, Revised July 23, 2019, Accepted for publication August 7, 2019

Corresponding author: Sung-Ae Kim, Department of Dermatology, Keimyung University School of Medicine, 56 Dalseong-ro, Jung-gu, Daegu 41931, Korea. Tel: 82-53-250-7624, Fax: 82-53-250-7626, E-mail: skksasf@ hanmail.net ORCID: https://orcid.org/0000-0002-6040-6630

This is an Open Access article distributed under the terms of the Creative Commons Attribution Non-Commercial License (http://creativecommons. org/licenses/by-nc/4.0) which permits unrestricted non-commercial use, distribution, and reproduction in any medium, provided the original work is properly cited.

Copyright $($ The Korean Dermatological Association and The Korean Society for Investigative Dermatology 